\title{
INFORMACIONO-KOMUNIKACIONA TEHNOLOGIJA KAO PODRŠKA UPRAVLJANJU VANREDNIM SITUACIJAMA
}

\author{
Brankica Popović ${ }^{1}$, Kristijan $\mathrm{Kuk}^{2}$, Nenad Milic ${ }^{3} \quad$ UDK=004:614.8 \\ https://doi.org/10.18485/fb_ubur.2018.1.ch8 \\ ${ }^{1}$ Kriminalističko-policijski univerzitet, Beograd, brankica.popovic@kpa.edu.rs \\ ${ }^{2}$ Kriminalističko-policijski univerzitet, Beograd, \\ kristijan.kuk@kpa.edu.rs \\ ${ }^{3}$ Kriminalističko-policijski univerzitet, Beograd, nenad.milic@kpa.edu.rs
}

\section{Sažetak}

Zakon o vanrednim situacijama (Sl. glasnik RS, br. 111/2009, 92/2011 i 93/2012) u članu 8, tačka 1, definiše vanrednu situaciju kao 'stanje kada su rizici i pretnje ili posledice katastrofa, vanrednih događaja i drugih opasnosti po stanovništvo, životnu sredinu i materijalna dobra takvog obima i intenziteta da njihov nastanak ili posledice nije moguće sprečiti ili otkloniti redovnim delovanjem nadležnih organa i službi, zbog čega je za njihovo ublažavanje i otklanjanje neophodno upotrebiti posebne mere, snage i sredstva, uz pojačan režim rada'. Pri tome se pod katastrofom podrazumeva elementarna nepogoda ili druga nesreća i događaj koji veličinom, intenzitetom i neočekivanošću ugrožava zdravlje i živote većeg broja ljudi, materijalna dobra i životnu sredinu, kao i nesreća nastala ratnim razaranjem ili terorizmom. Upravljanje vanrednim situacijama predstavlja proces usmeravanja subjekata zaštite i spasavanja u izvršavanju njihovih obaveza i zadataka (Zakon o vanrednim situacijama, Sl. glasnik RS, br. 111/2009, 92/2011 i 93/2012), član 8, tačka 17), sa posebnim akcentom na spremnosti, odgovoru i oporavkom, radi ublažavanja posledica katastrofe (V. Cvetković 2016). Efikasnost odgovora zavisi od sposobnosti da se brzo proceni situacija i mobilišu neophodni resursi, što je značajno olakšano upotrebom informaciono-komunikacionih tehnologija (IKT) i sistema.

Moderno društvo svoje aktivnosti zasniva na skoro neograničenom pristupu informacijama (sa bilo kojeg mesta u ma koje vreme), što ga čini gotovo zavisnim od upotrebe interneta i savremenih tehnologija u mrežnom okruženju. Mnogi su aspekti razvoja novih IKT, ali možemo reći da je poslednjih godina fokus na (Brankica M. Popović, Miloš Banđur, Anđelija Raičević 2014):

- konvergenciji mreža i usluga, kao i evoluciji mobilnih: uređaja, mreža, operativnih sistema i aplikacija;

- razvoju i personalizaciji interneta kroz uvođenje lokacijskih usluga i servisa (locationbased services) koji koriste informaciju o fizičkoj lokaciji korisnika ili uređaja kako bi obezbedili ciljane informacije;

- mapiranju fizičkih objekath u cyber-subjekte sa mogućnošću međusobne (pametne) interakcije - internet stvarî (Internet of Things - IoT);

- ekspanziji društvenih medija i mreža (social media, social networks) i korišćenju računarskih sistema zasnovanih na vebu (cloud computing); 
- proizvodnji i distribuciji sadržaja preko više platformi. Tako distribuirani izvori podataka (senzorske mreže, IoT, društvene mreže...) generišu obilje informacija koji se mogu analizirati (big data analytics) u smislu donošenja boljih odluka, ali i u kontekstu razumevanja mesta njihovog nastanka radi percepcije i razumevanja onoga što se dešava u složenom okruženju (situational awareness), što je od posebnog značaja za bezbednost, nadzor, upravljanje katastrofama, monitoring životne sredine i slične kategorije. Kombinovanjem informacija iz društvenih i senzorskih mreža podaci se transformišu u viši oblik kolektivne svesti, gde pretraga, analiza (data mining) i tehnologije vizuelizacije omogućavaju da se uoče trendovi i predvide putanje varijabli višeg nivoa (Pitt, J., et al. 2013).

Kada je u pitanju upravljanje vanrednim situacijama, u studiji (R. Murphy et al. 2012). iz 2012. godine identifikovano je sedam načina na koje IKT može unaprediti taj proces, među kojima su: poboljšana akvizicija a priori i podataka u realnom vremenu; prenos i transformacija podataka radi poboljšanja situational awareness; optimizacija korišćenja resursâ i logistike, ali i pomoć pri oporavku ili identifikaciji žrtava i spajanja porodica; i druge operacije.

Jasna je potreba da se prikupe, analiziraju i distribuiraju pouzdane i pravovremene informacije usred haotičnog okruženja izazvanog katastrofom. Tako implementacija (integrisanog) informacionog sistema (IS) može obezbediti adekvatan protok informacija u realnom vremenu kako bi se ubrzalo donošenje odluka. Uvođenjem prostorne odrednice podataka u IS, odnosno korišćenjem tzv. geografskih informacionih sistema (GIS), omogućeni su vizuelizacija i generisanje tzv. 'mapa rizika', kao i prognoza mogućeg razvoja faktora rizika. Povezivanje tehnologija kao što su IoT, pametni senzori i sveprisutno (ubiquitous) računarstvo sa nosivim (wearable) i ručnim računarima, bežičnim komunikacionim mrežama visoke propusne moći i senzorskim mrežama vitalni su za unapređenje efikasnosti odgovora u vanrednim situacijama.

Posebna pažnja se posvećuje komunikacionim tehnologijama i platformama za uspostavljanje sigurnog i brzog načina informisanja u ugroženom području. U tom smislu se, pogotovo u urbanim sredinama, društveni mediji mogu iskoristiti za plasiranje bitnih informacija ugroženom stanovništvu, ali i za komuniciranje i dobijanje relevantnih informacija kako od građanstva (crowdsourced) (P. Meier 2011) tako i od članova timova za reagovanje, tokom katastrofičnog događaja (C. Alfred et al. 2016). Primeri za to su uragan Sendi (Hurricane Sandy) u Centralnoj i Severnoj Americi, zemljotres u Italiji (Emilia earthquake), oba u 2012. godini, i zemljotres u Nepalu 2015, kada su mobilni uređaji i drušveni mediji korišćeni za razmenu informacija (M. Avvenuti et al. 2016). Kao glavni nedostatak smatra se nepouzdanost tih crowdsourced informacija (A.H. Tapia et al. 2011), a nije redak ni slučaj da društvene mreže budu zagušene obmanjujućim (lažnim) informacijama (glasinama), koje mogu dodatno uneti paniku u stanovništvo i gde je potrebno odvojiti dodatne resurse radi njihovog suzbijanja (R. Murphy 2016). Ovi i drugi izazovi ukazuju na mogućnosti dodatnih istraživanja u oblasti filtriranja podataka, klasifikacije teksta, obrade slike, kognitivnom računarstvu i sličnim područjima radi rešavanja uočenih problema.

Ključne reči: informaciono-komunikacione tehnologije, vanredna situacija, cloud/edge/fog računarstvo, senzorske mreže, društvene mreže, crowdsourcing 


\section{Uvod}

Svedoci smo da su vanredne situacije (pre svih regionalne katastrofe) porasle u broju, veličini i destruktivnoj moći. One obično ugrožavaju sve veći broj ljudi i veća područja na najraznovrsnije načine. Zato efikasna borba protiv njih podrazumeva planiranje i pripremu unapred, uprkos neizvesnosti u odnosu na vreme nastanka, specifičnu vrstu katastrofe, njenu snagu i posledice. Pristup pouzdanim, tačnim i pravovremenim informacijama, neposredno pre, tokom i posle njenog završetka, od vitalnog je značaja za proces upravljanja vanrednom situacijom. U tom procesu neizostavna je uloga informaciono-komunikacionih tehnologija (IKT). U radu je dat pregled trenda razvoja novih tehnologija i ukazano je na mogućnost njihove primene u procesu upravljanja vanrednim situacijama.

Zakon o vanrednim situacijama ${ }^{1}$ u članu 8 , tačka 1 , definiše vanrednu situaciju kao 'stanje kada su rizici i pretnje ili posledice katastrofa, vanrednih događaja i drugih opasnosti po stanovništvo, životnu sredinu i materijalna dobra takvog obima i intenziteta da njihov nastanak ili posledice nije moguće sprečiti ili otkloniti redovnim delovanjem nadležnih organa i službi, zbog čega je za njihovo ublažavanje i otklanjanje neophodno upotrebiti posebne mere, snage i sredstva uz pojačan režim rada'. Pri tome se pod katastrofom podrazumevaju elementarna nepogoda ${ }^{2}$ ili druga nesreća, ${ }^{3}$ ali i događaj koji veličinom, intenzitetom i neočekivanošću ugrožava zdravlje i živote većeg broja ljudi, materijalna dobra i životnu sredinu, kao i nesreća nastala ratnim razaranjem ili terorizmom. Danas su regionalne katastrofe (mnoge od njih izazvane ljudskim aktivnostima) porasle u broju, veličini i destruktivnoj moći, ugrožavajući sve veći broj ljudi i veća područja. Zato efikasna borba protiv katastrofe uvek znači planirati i pripremiti se unapred, čak i ako katastrofe podrazumevaju značajnu meru neizvesnosti u odnosu na vreme nastanka, specifičnu vrstu katastrofe, njenu snagu i posledice.

Upravljanje vanrednim situacijama ${ }^{4}$ predstavlja proces usmeravanja subjekata zaštite i spasavanja u izvršavanju njihovih obaveza i zadataka, sa posebnim akcentom na spremnost, odgovor i oporavak, radi ublažavanja posledica katastrofe (Cvetković, 2016). Pristup pouzdanim, tačnim i pravovremenim informacijama, neposredno pre, tokom i nakon katastrofe, od vitalnog je značaja za proces upravljanja vanrednom situacijom. U suprotnom bi pojedinci i institucije bili prisiljeni da donesu ključne odluke zasnovane na neproverenim, nedovršenim i konfliktnim izveštajima. Pri tome se mora uzeti u obzir da katastrofa može značajno uticati na

1 Zakon o vanrednim situacijama (Sl. glasnik RS, br. 111/2009, 92/2011 i 93/2012).

2 Događaj hidrometeorološkog, geološkog ili biološkog porekla, prouzrokovan delovanjem prirodnih sila (npr. zemljotres, poplava, oluja, gràd, suša, klizanje zemljišta, lavina, epidemija zaraznih bolesti i druge nesreće).

3 Tehničko-tehnološke nesreće, kao što su požar, eksplozija, havarija, saobraćajni udes, udes u rudnicima i tunelima, rušenje brana, havarija na elektroenergetskim, naftnim ili gasnim postrojenjima, akcidenti pri rukovanju radioaktivnim i nuklearnim materijama i slične neprilike.

4 Zakon o vanrednim situacijama (Sl. glasnik RS, br. 111/2009, 92/2011 i 93/2012), član 8, tačka 17. 
sposobnost pojedinaca koji su uključeni u zaštitu i spasavanje da efikasno i efektivno rukuju informacijama. Ovo se može dogoditi zbog njihove nemogućnosti da se nose sa obiljem informacija i kratkih rokova u kojima moraju da donesu odluku, ali i zbog uslova u kojima deluju, a koji mogu biti opasni po život.

Kako efikasnost odgovora zavisi od sposobnosti da se brzo proceni situacija i mobilišu neophodni resursi, jasna je potreba za postojanjem robustnog sistema za upravljanje informacijama usred haotičnog okruženja izazvanog katastrofom, pa se nameće imperativ upotrebe informaciono-komunikacionih tehnologija (IKT) u tom procesu. Tako implementacija (integrisanog) informacionog sistema (IS) može obezbediti adekvatan protok informacija u realnom vremenu kako bi se ubrzalo donošenje odluka. Uvođenjem prostorne odrednice podataka u IS, odnosno korišćenjem tzv. geografskih informacionih sistema (GIS), omogućeni su vizuelizacija i generisanje tzv. 'mapa rizika', kao i prognoza mogućeg razvoja faktora rizika.

U slučaju katastrofe je neophodno preneti informacije 'u pravom trenutku i pravom obliku pravoj osobi', pa je posebna pažnja posvećena komunikacionim sistemima koji obezbeđuju razmenu informacija između subjekata zaštite i spasavanja i stanovništva u ugroženom području. U tom smislu se često govori o upotrebi radija i televizije, telefona (fiksnih i mobilnih), SMS poruka, amaterskih radio-sistema, interneta i elektronskih poruka (Wattegama, 2007). Pri tome je neophodno uzeti u obzir pouzdanost i dostupnost informacionih kanala u uslovima katastrofe recimo, ukoliko bi došlo do nestanka električne energije, televizijske poruke bi bile beskorisne.

U nedavnim katastrofama koje su zadesile svet (teroristički napadi, zemljotresi, cunamiji, uragani, poplave...) IKT su imale značajnu ulogu u reagovanju na njih. Pokazalo se, međutim, da komunikacija nije uvek bila moguća, zbog oštećenja komunikacione infrastrukture i preopterećenosti mobilnih mreža, što je zahtevalo razvoj novih efektivnih strategija za upravljanje katastrofama. $\mathrm{U}$ tom postupku će značajnu ulogu imati nove tehnologije u razvoju.

Tako je dinamičan i intenzivan razvoj IKT i senzorskih tehnologija doneo potpuno nove, doskora nezamislive, načine upravljanja informacijama, odnosno njihovog prikupljanja, obrade i distribucije. Primenom nove tehnologije moguće je, recimo, dodatnim senzorima 'proširiti' ljudska čula da otkriju situacije (npr. radioaktivnost) koje je nemoguće detektovati normalnim ljudskim receptorima. Povezivanje tehnologija kao što su IoT, pametni senzori i senzorske mreže te sveprisutno (ubiquitous) računarstvo sa bežičnim komunikacionim mrežama visoke propusne moći od vitalnog je značaja za unapređenje efikasnosti upravljanja vanrednim situacijama.

Cilj ovog rada je upravo da ukaže na nove mogućnosti koje moderne tehnologije, a pre svih informaciono-komunikacione, donose u oblasti upravljanja vanrednim situacijama. U tom smislu je rad organizovan u dve celine. U prvoj su objašnjeni trendovi razvoja savremenih IKT, a u drugoj su prikazane mogućnosti primene te tehnologije u procesu upravljanja vanrednim situacijama. 


\section{Trendovi razvoja novih tehnologija}

Iako niko ne može da sa sigurnošću predvidi vremenske okvire i modalitete razvoja novih tehnologija, nekoliko ozbiljnih svetskih istraživačkih i savetodavnih kompanija svake godine daje svoje prognoze. Tako Gartner, ${ }^{1}$ kao jedna od vodećih u toj oblasti, između ostalih, pruža svoje viđenje trendova razvoja strategijskih tehnologija. Vodećih 10 koje su nagovestili za period 2015-2017. godine prikazano je u tabeli 1 .

Analiza ukazuje da ćemo u budućnosti imati sve gušću mrežu povezanih uređaja (Device Mesh), koja obuhvata ne samo računare i mobilne uređaje već i širok opseg drugih uređaja sa kojima ljudi mogu biti u interakciji. Povećan je broj senzora koji se ugrađuju u uređaje koje ljudi koriste profesionalno ili privatno (Internet of Things, IoT), a sve češće u stvari koje nosimo na nama ili sa nama (wearables). Pri tome će ovi uređaji i senzori biti sposobni da sakupe više kontekstnih podataka u realnom vremenu koje ce aplikacije koristiti (Ambient User Experience), što će dovesti do još većih uvida u naše dnevne obrasce.

Tabela 1. Top 10 Strategic Technology Trends za period 2015-2017.

\begin{tabular}{|c|c|c|}
\hline 2015 & 2016 & 2017 \\
\hline $\begin{array}{l}\text { Merging the Real } \\
\text { World and Virtual } \\
\text { World }\end{array}$ & $\begin{array}{c}\text { Digital Mesh } \\
\text { Intelligent }\end{array}$ & \\
\hline Computing Everywhere & Device Mesh & $\begin{array}{c}\text { Artificial Intelligence and } \\
\text { Advanced Machine } \\
\text { Learning }\end{array}$ \\
\hline The Internet of Things & $\begin{array}{l}\text { Continuous \& Ambient } \\
\text { User Experience }\end{array}$ & Intelligent Apps \\
\hline 3D Printing & 3D-Printing Materials & Intelligent Things \\
\hline $\begin{array}{l}\text { Intelligence } \\
\text { Everywhere }\end{array}$ & Smart Machines & Digital \\
\hline $\begin{array}{l}\text { Advanced, Pervasive and } \\
\text { Invisible Analytics }\end{array}$ & $\begin{array}{l}\text { Information of } \\
\text { Everything }\end{array}$ & $\begin{array}{l}\text { Virtual Reality and } \\
\text { Augmented Reality }\end{array}$ \\
\hline Context-Rich Systems & $\begin{array}{l}\text { Advanced Machine } \\
\text { Learning }\end{array}$ & Digital Twins \\
\hline Smart Machines & $\begin{array}{l}\text { Autonomous Agents } \\
\text { and Things }\end{array}$ & $\begin{array}{l}\text { Blockchains and } \\
\text { Distributed Ledgers }\end{array}$ \\
\hline
\end{tabular}




\begin{tabular}{ccc}
\hline $\begin{array}{c}\text { The New IT Reality } \\
\text { Emerges }\end{array}$ & New IT Reallity & Mesh \\
Cloud/Client Computing & Adaptive Security & Conversational Systems \\
& Architecture & \\
$\begin{array}{c}\text { Software-Defined } \\
\text { Applications and } \\
\text { Infrastructure }\end{array}$ & Advanced System & Digital Technology \\
Architecture & Platforms \\
Web-Scale IT & Mesh App and Service & $\begin{array}{c}\text { Mesh App \& Service } \\
\text { Architecture }\end{array}$ \\
$\begin{array}{c}\text { Risk-Based Security and } \\
\text { Self-protection }\end{array}$ & $\begin{array}{c}\text { Internet of Things Ar- } \\
\text { chitecture and Platforms }\end{array}$ & $\begin{array}{c}\text { Adaptive Security } \\
\text { Architecture }\end{array}$ \\
\hline
\end{tabular}

Prema Gartner-u, do 2020. godine 25 milijardi povezanih uređaja generisaće podatke o skoro svim temama koje se mogu zamisliti, što predstavlja, sa jedne strane, veliku mogućnost, ali, sa druge, i veliki izazov kako dati smisao tom obilju podataka (Information of Everything, IoE). Tehnologije i standardi IoT-platforme (Internet of Things Architecture and Platforms) predstavljaju osnovni skup mogućnosti za komuniciranje, kontrolu, upravljanje i obezbeđivanje krajnjih tačaka u IoT-u. Gartner ukazuje na to da su ponuđači IoT-platformi danas fragmentirani i da bi im značajno koristilo povezivanje u sistem u kojem se podaci šire razmenjuju. Dalje, po njihovom viđenju, digitalne usluge će biti omogućene svima/svemu, a inteligencija će biti ugrađena u praktično sve. Ovu mrežu povezanih ljudi, uređaja, sadržaja i usluga Gartner naziva inteligentnom digitalnom mrežom (Intelligent Digital Mesh $)^{1}$ i biće ukratko objašnjena u nastavku.

\section{Inteligentna (Intelligent) tehnologija}

Smatra se da su veštačka inteligencija i napredno mašinsko učenje (Artificial Intelligence AI \& Advanced Machine Learning) dostigli kritičnu tačku gde će se sve više uključivati u skoro svaku uslugu, stvar ili aplikaciju omogućenu tehnologijom. Ono će omogućiti pomeranje sa pametnih mašina ka inteligentnim sistemima koji razumeju, uče, adaptiraju se (menjaju buduće ponašanje) i potencijalno deluju samostalno. Dolazi do implementacije spektra inteligentnih aplikacija i stvari (Intelligent Apps \& Things) - uključujući virtuelne personalne asistente (VPA) i pametne savetnike, kao i robote, autonomna vozila i bespilotne letelice (dronove), koji deluju na autonoman način. Kako se inteligentne stvari razvijaju i postaju popularnije, one će prelaziti sa samostalnog u kolaborativni (zajednički) model rada, u kojem inteligentne stvari komuniciraju jedne s drugima i deluju $u$ dogovoru kako bi izvršile zadatke.

1 https://www.forbes.com/sites/peterhigh/2016/10/24/understanding-the-top-ten-technology-trendsfor-2017/\#5c2ede055b9e, pristupano 15. 5. 2017. 
Digitalna (Digital) tehnologija

Kognitivna transformacija IoT-aplikacija omogućiće korišćenje optimizovanih rešenja za individualne korisnike i integraciju tehnologija virtuelne realnosti $(V R)$ i proširene realnosti (AR) (Virtual \& Augmented Reality), kao koncepata koji transformišu način na koji ljudi komuniciraju jedni sa drugima, sa mašinama i softverskim sistemima. U budućem periodu milijarde fizičkih stvari/sistema biće predstavljene svojim dinamičkim softverskim modelima, nazvanim digitalni blizanci (Digital Twins), koji se mogu iskoristiti za analizu, modelovanje, simulaciju, predikciju i kontrolu stanja u stvarnom svetu. U tom digitalnom svetu sve će se više koristiti Blockchain-tehnologija, kao jednostavan, revolucionarni protokol koji dozvoljava da transakcije budu istovremeno anonimne i sigurne, eliminišući potrebu za centralnim telom od poverenja uvođenjem distribuiranog konsenzusa (Tapscott \& Tapscott, 2016). Najpoznatiji primer ove tehnologije danas je Bitcoin, odnosno digitalna valuta - međutim, ona ima potencijal da bude primenjena virtuelno na bilo koju vrednost u digitalnom svetu (odnosi se ne na novac, već na informaciju).

\section{Mreža (Mesh)}

Podršku inteligentnim digitalnim ekosistemima pružaće mreža koja evoluira fundamentalno menjajući korisničko iskustvo. Uvode se konverzacioni sistemi (Conversational Systems), koji omogućavaju da, umesto interakcije sa menijima, formama i dugmadima na pametnom telefonu, sa računarima komuniciramo prirodnim jezikom, i to višestrukim modalitetima (npr. vid, zvuk, dodir itd). To znači pomeraj od modela gde se ljudi prilagođavaju računarima na mesto gde računar 'čuje' i prilagođava se ljudima. Inteligentna digitalna mreža zahteva promene u arhitekturi, tehnologiji i alatima korišćenim za razvoj rešenja. Arhitektura mrežnih aplikacija i usluga (Mesh App and Service Architecture - MASA) koristiće cloud/fog/edge computing za isporučivanje modularnih, fleksibilnih i dinamičnih rešenja koja podržavaju više korisnika u više uloga, upotrebljavajući više uređaja i komunikaciju preko više mreža. Digitalne tehnološke platforme (Digital Technology Platforms) biće osnovni elementi digitalnog poslovanja, što će zahtevati i nova sigurnosna rešenja za to okruženje (Adaptive Security Architecture).

U nastavku će ukratko biti objašnjeni savremeni koncepti IKT, odnosno računarstva (computing), koji su u fazi upotrebe ili uvođenja.

\subsection{Senzorske mreže}

Senzorska mreža predstavlja sistem koji čini polje senzora raznolikog tipa, međusobno povezanih komunikacionom mrežom. Sadrži individualne (multifunkcionalne) senzorske čvorove sposobne da prate promene u fenomenu koji nadgledaju i da lokalno obrađuju podatke i prosleđuju ih drugim čvorovima (agregatorima) i/ili uređajima. Tako se mogu nadzirati brojni fizički parametri značajni za detekciju promena u sredini koja se kontroliše, kao što su vlažnost, temperatura, 
zvuk, pritisak, brzina i pravac, koncentracije hemikalija, vibracije, nivoi zagađujućih materija i druge veličine. Danas su od posebnog značaja bežične senzorske mreže (Wireless Sensor Network - WSN), kod kojih su senzorski čvorovi bežičnim putem povezani u komunikacionu mrežu.

\subsection{Prožimajuće/sveprisutno računarstvo}

Sa kontinuiranim razvojem IKT, vidljiv je pokret ka sveobuhvatnoj upotrebi mreža i računarske moći, odnosno dobu koje je Mark Vajzer (Weiser, 1991) nazvao 'sveprisutno računarstvo'. Prema njegovoj (pionirskoj) viziji, računar kao namenski uređaj trebalo bi da nestane, dok će istovremeno mogućnosti za obradu informacija biti dostupne svuda u našem okruženju.

Koncept sveprisutnog računarstva (ubiquitous computing) i, kasnije, prožimajućeg računarstva (pervasive computing) ${ }^{1}$ predstavlja rastući trend ugrađivanja računarske sposobnosti u svakodnevne objekte kako bi efikasno komunicirali i obavljali zadatke na način koji minimizuje potrebu uključivanja krajnjeg korisnika. ${ }^{2} \mathrm{Ti}$ objekti su mrežno povezani i konstantno dostupni, a ne uključuju samo mobilne računare, pametne telefone i tablete, već i druge različite aparate i senzore. Jedan od načina na koje je moguće postići da računari postanu prožimajući element naših života predstavlja i njihova ugradnja u odeću i druge delove opreme koju neprekidno nosimo na sebi ili sa sobom (wearable devices). Primeri takvih uređaja su, recimo, pametni satovi koji mogu komunicirati sa pametnim telefonom, prikazivati vremensku prognozu, slati poruke, meriti broj otkucaja srca i drugo, ili posebni naočari na kojima je moguće projektovati sliku s pametnog telefona ili računara ugrađenog u odeću. ${ }^{3}$

Cilj sveprisutnog i prožimajućeg računarstva, inače često smatranih naslednicima mobilnog računarstva (mobile computing), jeste da uključivanjem računarske moći uređaje učini 'pametnim/inteligentnim'. To je omogućeno stvaranjem senzorske mreže koja može prikupljati, obrađivati i slati podatke, tj. mreže uređaja koji su kadri da razumeju svoju okolinu, te u skladu s tim realizuju funkcije prilagođene kontekstu i aktivnostima podataka, a na taj način poboljšaju ljudsko iskustvo i kvalitet života (Mattern, 2001). Sposobnost uređaja ili programa da prepoznaju, osete, reaguju ili se prilagode različitim parametrima iz okoline ${ }^{4}$ (što se opisuje kao kontekst) naziva se i kontekstno računarstvo, odnosno računarstvo koje reaguje na kontekst (context-aware computing).

Sveprisutno/prožimajuće računarstvo ima cilj i da računarsku moć učini dostupnom u svakom trenutku i na svakome mestu, tako što će biti ugrađena u

1 Koristili su se različiti termini: Proactive Computing, Sentient Computing, Ambient Intelligence, Internet of Things, Everyware, Pervasive Computing. Danas su dominantno u upotrebi termini (često kao sinonimi) Ubiquitous Computing/Pervasive Computing i Internet of Things.

2 http://internetofthingsagenda.techtarget.com/definition/pervasive-computing-ubiquitous-computing pristupano 20. 5. 2017.

3 http://www.wearables.com/, pristupano 16. 5. 2017.

4 To mogu biti senzorske informacije ili drugi podaci, uključujući stavove korisnika. 
stvari koje nas okružuju do nivoa da će postati deo našeg svakodnevnog života, sveprisutna i nevidljiva. Ova vizija je zasnovana na uverenju da će mikroprocesori i napredni senzori uskoro biti toliko mali i jeftini da će se moći ugraditi u gotovo sve. Milijarde takvih objekata će biti isprepletene i bežično povezane da bi se formirao internet stvarî (IoT). Zato se glavnim karakteristikama sveprisutnog/prožimajućeg računarstva smatraju: nevidljivost, autonomnost, prilagodljivost, proaktivnost, svesnost konteksta, mobilnost i sigurnost, a primenu nalaze u različitim oblastima, počev od energetike, zdravstva, proizvodnje i logistike, transporta i drugih.

\subsection{Internet stvarî - IoT}

Internet stvarî $(I o T)$ jeste mrežna paradigma u kojoj je svaki fizički objekt mapiran kao jedan (ili više) kiber-subjekata koji mogu da automatizovano komuniciraju jedni sa drugima i razmenjuju podatke (Feki et al, 2013). Broj uređaja povezanih na internet eksponencijalno raste i već je premašio broj ljudi povezanih na internet (Tung, 2017). Praćenjem tendencije rasta procenjeno je da će već 2018. godine broj povezanih senzora, potrošačkih uređaja i industrijskih kontrolnih sistema značajno premašiti broj pametnih telefona i drugih mobilnih uređaja, koji su, opet, višestruko brojniji od personalnih računara i servera (Columbus, 2016).

Danas se smatra da je IoT samo privremena stanica (prelazni korak) na putu ka sveprisutnom/prožimajućem računarstvu (slika 1). Naime, vizija sveprisutnog/prožimajućeg računarstva jeste da se računarska moć raširi kroz naš svakodnevni život, svuda, u stvari koje nas okružuju ili koje koristimo, kada računari zapravo prestaju da budu odvojeni entitet o kojem će se govoriti. ${ }^{1}$ IoT je na putu ka obezbeđivanju ove vizije, ali za sada zahteva dosta napora prilikom konfiguracije, kao i veći obim ljudske interakcije (koja, inače, u viziji prožimajućeg računarstva ne postoji - odnosno, računarska moć je podrazumevana i 'nevidljiva').

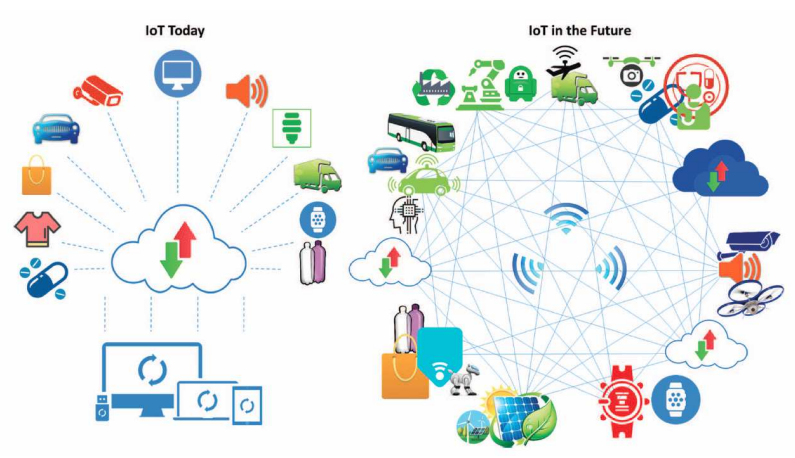

Slika 1. Pomeraj od centralizovanog oblaka ka distribuiranoj platformi edge IoT i aplikacijama (izvor: Vermesan \& Bacquet, 2017)

1 https://jaredporcenaluk.com/internet-of-things-vs-ubiquitous-computing-vs-pervasive-computing/, pristupano 10. 5. 2017. 
$\mathrm{U}$ viziji IERC-a (European Research Cluster on the Internet of Things) ${ }^{1}$ glavni cilj IoT-a je stvaranje pametnih okruženja/prostora i samosvesnih stvari za različite aplikacije za digitalno društvo. To pred mrežne tehnologije postavlja nove izazove, kao što su obezbeđivanje visoke brzine prenosa podataka, podrške značajno povećanom broju korisnika/uređaja, nisku latenciju (kašnjenje), nisku potrošnju energije i nisku cenu. Ovaj koncept dodatno potencira pitanja informacione bezbednosti i sa njima povezanih pitanja bezbednosti sistema, mreža i aplikacija, kao i, naravno, uvek aktuelna pitanja očuvanja privatnosti (Popović et al., 2014).

Ništa manji izazov nije kako rešiti problem ogromne količine podataka koju će generisati IoT uređaji. Sve te podatke treba spremiti, analizirati i iz njih izvući korisne informacije i zaključke. Za to se mogu iskoristiti tehnologije kao što su obrada 'velikih podataka'2 (big data processing), mašinsko učenje i veštačka inteligencija. Jedno od rešenja je da se ti podaci čuvaju u oblaku (cloud), gde će se analizirati (big data analytics), a zatim po njima i delovati.

Analiza tog obilja podataka u kontekstu razumevanja mesta njihovog nastanka naziva se situaciona svest (situational awareness) i odnosi se na percepciju i razumevanje onoga što se dešava u složenom okruženju. To je od velikog značaja za bezbednost, nadzor, upravljanje katastrofama i monitoring životne sredine. Recimo još da metode utvrđivanja situacione svesti u praksi danas često kombinuju informacije iz društvenih i senzorskih mreža, transformišući te velike podatke u viši oblik kolektivne svesti, gde pretraga, analiza (data mining) i tehnologije vizuelizacije omogućavaju da se uoče trendovi i predvide putanje varijabli višeg nivoa (Pitt et al., 2013).

\subsection{Računarstvo u oblacima (Cloud Computing)}

Računarstvo u oblacima (Cloud computing, termin 'oblak' je u suštini metafora za internet) odnosi se na upotrebu na web-u zasnovanih računarskih sistema, aplikacija i usluga kojima se pristupa nezavisno od infrastrukture. Ovo omogućava da računarske usluge budu dostupne gde i kada je to potrebno kroz servise: infrastruktura kao servis $(I a a S)$, platforma kao servis $(P a a S)$ i softver kao servis $($ SaaS $)$. Koncept omogućava manje troškove, pristup nezavisan od tipa uređaja i lokacije, istovremeno deljenje i iznajmljivanje (na komercijalnoj bazi) resursa/servisa brojnim korisnicima, kao i njihovu skalabilnost.

Ekspanzija računarstva u oblacima danas omogućava koncept 'bilo šta kao usluga' (XaaS - or anything as a service). ${ }^{3}$ Kako su, međutim, resursi izmešteni i pristupa im se putem interneta, modeli zasnovani samo na oblaku (Cloud-only models) suočavaju se sa ozbiljnim izazovima u smislu latentnosti, širine propusnog

1 http://www.internet-of-things-research.eu/, pristupano 13. 5. 2017.

2 Odnosi se na masivan, heterogen i često nestrukturiran digitalni sadržaj koji je teško obraditi korišćenjem tradicionalnih alata i tehnika upravljanja podacima.

3 https:/www.forbes.com/sites/danielnewman/2017/01/03/17-top-enterprise-tech-trends-for-2017and-this-years-ces/2/\#14a3982f4723, pristupano 10. 5. 2017. 
opsega mreže, geografskog fokusa, pouzdanosti i bezbednosti, te ne predstavljaju održiv koncept za mnoge IoT-aplikacije. Kao moguće rešenje ovog problema uvode se koncepti računarstva na ivici (edge computing) i računarstva u magli (fog computing).

\subsection{Računarstvo na ivici (edge computing) i računarstvo u magli (fog computing)}

Ukoliko se sveukupno prikupljanje i obrada podataka vrši na nivou ivičnog (edge) uređaja/senzora/aktuatora koji uključuju mikrokontrolerske module za obradu i bežične module za komuniciranje, onda govorimo o računarstvu na ivici (edge computing). Softver na krajnjem uređaju podržava uređaje da koriste svoje mogućnosti razmene podataka i donošenja odluka za interakciju i saradnju kako bi obradili podatke na samom kraju, filtrirali i odabrali/prioritizovali ono što je važno za prenos u centralne repozitorijume podataka u oblaku. Ovo omogućava uključivanje edge cloud-a za obradu podataka i rešavanje izazova odzivnog vremena, pouzdanosti i sigurnosti.

Međutim, uređaji i senzori na mestu gde se podaci generišu i prikupljaju često nemaju resurse za njihovu obradu i skladištenje, kao ni za obavljanje naprednih analitičkih zadataka. Iako serveri u oblaku (cloud servers) imaju moć da to učine, oni su često previše udaljeni da bi obradili podatke i blagovremeno reagovali. Osim toga, činjenica da svi povezani krajnji uređaji šalju sirove podatke u oblak može imati pravne i implikacije za privatnost i sigurnost/pouzdanost, posebno kada je reč o ličnim i osetljivim podacima. Računarstvo u magli ${ }^{1}$ (fog computing) predstavlja decentralizovanu računarsku infrastrukturu u kojoj se podaci, obrada, skladištenje i aplikacije distribuiraju na najlogičnije i najefikasnije mesto između izvora podataka i oblaka. Računarstvo u magli u suštini proširuje računarstvo u oblaku i njegove usluge na ivicu mreže, što donosi prednost i moć cloud-a bliže mestu gde se podaci stvaraju i gde se po njima deluje. ${ }^{2}$

Cilj računarstva u magli čini poboljšanje efikasnosti i smanjenje količine podataka koji se prenose u oblak, pošto se obrada odvija u čvorištu podataka na pametnom uređaju ili u pametnom ruteru ili gateway-u. Važno je napomenuti da računarstvo u magli dopunjava, a ne zamenjuje računarstvo u oblaku. Ono omogućava kratkoročnu analizu na ivici mreže, dok se u oblaku izvodi intenzivna, dugoročna analitika.

Neki koriste izraze računarstvo u magli i računarstvo na ivici kao sinonime, pošto oba podrazumevaju približavanje inteligencije i obrade mestu gde se podaci stvaraju. Međutim, ključna razlika između njih sastoji se u tome gde se nalaze hardver i softver za obradu podataka. Kod računarstva u magli obrada je u lokalnoj mreži. Podaci se prenose sa krajnjih tačaka u gateway, odakle se onda prenose na

1 Metafora 'magla' potiče od meteorološkog pojma (kao i 'oblak') i označava pojavu blizu tla, odnosno aktivnost koja se koncentriše na ivici mreže, u sferi neizvesnosti.

2 http://internetofthingsagenda.techtarget.com/definition/fog-computing-fogging, pristupano 20. 5. 2017. 
uređaje za obradu i povratni prenos. Kod računarstva na ivici obrada je u uređajima kao što su programabilni automatizovani kontroleri. U svakom slučaju, pomeranje obrade na ivicu omogućiće i konsolidaciju protokola kontrolisanjem različitih načina na koje uređaji mogu komunicirati jedni s drugima. Kao deo ove konvergencije, aplikacije IoT-a (kao što je Sensing-as-a-Service) isporučivace se na zahtev preko cloud-okruženja (Yuriyama \& Kushida, 2010).

Popularne aplikacije računarstva u magli i računarstva na ivici uključuju pametne gradove (smart city) sa njihovim komponentama (pametne mreže, zgrade, transport, zdravlje i druge) (McMillin \& Zhang, 2017). Pametni gradovi uskoro će se suočiti sa potrebom integrisanog rešenja operativnog sistema (SmartCity-OS) kao osnove koja će gradovima pružati adaptivne alate i koji će generisati integraciju drugih IoT-sistema i poslovnih mogućnosti (Vermesan \& Bacquet, 2017).

\section{Primena novih tehnologija za upravljanje vanrednim situacijama}

Analizirajući reagovanje spasilačkih timova u konkretnim slučajevima katastrofe, identifikovana su tri glavna izazova pri korišćenju IKT (Murphy, 2016):

1. Potrebna je njihova ekstremna skalabilnost (extreme scalability) - u odnosu na:

a. vreme - vreme povezano sa nesrećom odnosi se na period pre nego što se ona dogodi (faze sprečavanja i spremnosti), dok se dešava (faza odgovora) i pošto se završi (faza oporavka);

b. prostor - od fizički malog prostora do nesreća na geografski velikim oblastima (npr. 2011. zemljotres u Japanu i prateći cunami);

c. aktere - vladine službe, nevladine organizacije (npr. Crveni krst), volonteri, članovi društvenih mreža, pojedinci i drugi subjekti;

d. podatke - postavlja se pitanje upravljanja velikom količinom podataka, koji su po prirodi heterogeni, na način da budu blagovremeni u smislu podrške donošenju odluka. Tu je i pitanje obezbeđenja privatnosti i sigurnosti/pouzdanosti privatnih i osetljivih podataka.

2. Moraju omogućiti računski složenu analizu katastrofa, pošto se, matematički, katastrofa ponaša kao nelinearni sistem koji je osetljiv na početne uslove i za koji ne postoji jedno optimalno rešenje.

3. Moraju obezbediti podršku donošenju odluka u ekstremnim uslovima, pri čemu je situaciona svest ključni element efikasnog odgovora. Spasilački timovi moraju biti sposobni da shvate, vizuelizuju i veruju podacima koje prikupljaju, a, s obzirom na fiziološke i kognitivne deficite usled rada u ekstremnim uslovima, ${ }^{1}$ donosiocima odluka je neophodna IKT podrška (Badiru \& Racz, 2013).

1 Panika, anksioznost, stres, zbunjenost, ugroženo zdravlje, prekomerna žurba, poricanje i drugo. 
Kada je u pitanju upravljanje vanrednim situacijama, u studiji iz 2012. godine (Murphy et al., 2012) pobrojano je sedam načina na koje IKT može unaprediti taj proces, među kojima su kao najznačajniji uočeni: poboljšana akvizicija a priori i podataka u realnom vremenu; prenos i transformacija podataka radi poboljšanja situacione svesti; optimizacija korišćenja resursâ i logistike, kao i pomoć pri oporavku ili identifikaciji žrtava i spajanja porodica.

Posebna pažnja se posvećuje komunikacionim tehnologijama i platformama za uspostavljanje sigurnog i brzog načina informisanja u ugroženom području. ${ }^{1}$ Telefonski sistemi službi za hitne intervencije i pomoć (policije - 192, vatrogasaca - 193, kao i hitne pomoći - 194) nisu osmišljeni za slučaj katastrofe, pa tako nisu u stanju da prioritizuju, odnosno da vrše trijažu na hiljade poziva. Pogodan sistem komunikacije u vanrednim situacijama treba da je pouzdan, skalabilan i od poverenja, odnosno takav da se na njega građani mogu osloniti za tačne informacije i uputstva. Ako je civilna komunikaciona infrastruktura oštećena, servisi se mogu brzo obnoviti korišćenjem mobilnih baznih stanica ili upotrebom letelica sa repetitorima bežičnog signala.

Tako su u Obrenovcu 2014. godine zbog poplava bazne stanice imale probleme sa snabdevanjem električnom energijom, pa je bila otežana, a ponegde i onemogućena komunikacija. Zato je VIP mobilni operater na lokaciji Mislođin postavio mobilnu baznu stanicu, a u saradnji sa MUP-om, koji ju je sa agregatima prevezao na sigurnu lokaciju, što je značajno poboljšalo pokrivenost mobilnog signala na glavnini opštinske teritorije Obrenovca (Gligorijevic et al., 2017). Shvativši koliko je nesmetana komunikacija neophodna za reagovanje u hitnim slučajevima, u SAD su pristupili razvoju posebne širokopojasne bežične mreže, namenjene samo službama spasavanja - FirstNet. ${ }^{2}$

Zaposleni u UNICEF-u smatraju da su najbolje tehnologije na terenu za upravljanje nesrećama jednostavne za korišćenje, lake za održavanje i jeftine. Oni promovišu Rapid SMS field-based communications system nazvan Bee. On predstavlja telekomunikacioni sistem za hitne slučajeve otvorenog koda koji pruža pristup internetu u oblastima u kojima infrastruktura nije postojala ili je neupotrebljiva. Obezbeđuje telefonsku uslugu i Wi-Fi pristup aplikacijama, može ga instalirati terenski radnik i biti operativan u roku od 30 minuta. Kada se oblast stabilizuje, sistem Bee se ostavlja na mestu da deluje kao osnova za novu komunikacionu infrastrukturu (Underwood, 2010).

Da bi se obezbedila interoperabilna komunikacija između različitih uređaja i bez oslanjanja na bazne stanice ili internet, na Univerzitetu Sirakuza (Syracuse University's School of Information Studies) razvili su alat iDAWG (Intelligent

1 Npr. The Google Crisis Response Team napravio je open source proizvode i servise za podršku ugroženima od prirodnih katastrofa, koji uključuju Google Person Finder, Google Crisis Map, Google Fusion Tables i Google Public Alerts. https://www.google.org/our-work/crisis-response/, pristupano 10. 5. 2017.

2 Više na: www.firstnet.gov, pristupano 28. 4. 2017. 
Deployable Augmented Wireless Gateway). ${ }^{1}$ On radi sa novom klasom softvera, nazvanom edgeware, koja povezuje uređaje i informacije te pomaže u komunikaciji između mašina (M2M, machine to machine). Proces je sličan ad hoc umrežavanju, gde se lokalna mreža gradi spontano kako se koji uređaj povezuje jedan sa drugim.

Danas se sve više, a pogotovo u urbanim sredinama, društveni mediji i mreže koriste za plasiranje vitalnih informacija ugroženom stanovništvu, ali i za komuniciranje i dobijanje relevantnih informacija kako od građanstva (crowdsourced) tako i od članova timova za reagovanje, tokom katastrofičnog događaja (Meier, 2011). U nastavku će biti objašnjena uloga društvenih mreža i medija, ali i širokog spektra 'pametnih' uređaja u sklopu IoT-a, u postupku upravljanja vanrednim situacijama.

\subsection{Društvene mreže i mediji (social network \& media)}

Društvene mreže i mediji (npr. Facebook, Twitter, blogovi) pojavljuju se kao efikasan alat za olakšavanje komunikacije, saradnje i koordinacije (communication, cooperation, and coordination) tokom vanrednih situacija. Tako se sveobuhvatna razmena podataka u realnom vremenu putem mobilnih uređaja i društvenih medija pokazala izuzetno korisnom u slučajevima uragana Sendi (Hurricane Sandy) u Centralnoj i Severnoj Americi i zemljotresa u Italiji (Emilia earthquake), oba u 2012. godini, i zemljotresa u Nepalu 2015. godine (Avvenuti et al., 2016). Zato je razumljiva inicijativa da se uvedu inovativni pristupi koji mogu spojiti podatke prikupljene od tradicionalnih fizičkih senzora sa onima iz tzv. 'društvenih senzora', odnosno sa informacijama dobijenim iz društvenih mreža (Meier, 2011).

Kako bi se radnici u službama za reagovanje u vanrednim situacijama na najbolji način pripremili za korišćenje društvenih mreža i medija za distribuciju pravovremenih, tačnih i koordiniranih informacija javnosti, firma Nusura Inc. je načinila alat SimulationDeck. ${ }^{2}$ Ovaj web-portal oponaša šta se dešava na mreži i u medijima tokom vanredne situacije te uključuje 9 web-stranica koje, između ostalog, imitiraju rad sa Facebook-om, Twitterom, bloging-platformama, YouTube-om, novinskim kanalima, radijskim i TV stanicama. On ne zahteva specijalni softver i može raditi na bilo kojoj platformi odnosno uređaju povezanom na internet, a alat je, pored ostalog, korišćen i od strane armije SAD tokom njihovih vežbi (Pittman, 2012).

Za dobijanje kontekstne informacije neophodne spasiocima iz podataka sa društvenih mreža primenjuju se različite tehnike. Neki od podataka (npr. Twitter) imaju geotagovane metapodatke (metadata), sa koordinatama geografske dužine i širine. Kod onih koji ne daju precizne geoprostorne informacije primenjuju se različite tehnike, kao što je npr. geoparsing (izvlačenje spominjanja poznatih lokacija

1 https://ischool.syr.edu/articles/news/view/wigits-idawg-communications-elements-progressing-tofield-test/, pristupano 20. 4. 2017.

2 http://www.nusura.com/, http://simulationdeck.com/, pristupano 22. 4. 2017. 
iz teksta poruke). Ovaj pristup pretvara društvene medije u virtualnu senzorsku mrežu koja omogućava prikupljanje i vizuelizaciju podataka (o šteti, povređenim i nestalim osobama).

Vizuelizacija informacija je dokazana tehnika za saopštavanje velikih, složenih i višeznačnih skupova podataka, kao i za njihovo 'prevođenje' u primenljivo znanje (Spence, 2014). Geografski informacioni sistemi (GIS) obezbeđuju da se informacijama doda i prostorna odrednica, čime je omogućena njihova vizuelizacija u formi mapiranja. Krizno mapiranje (na web-u zasnovano nazvano 'živo mapiranje', online mapiranje) povećava situacionu svest, dajući u realnom vremenu vizuelizaciju podataka koji su prikupljeni od strane mnogih pojedinaca (Goolsby, 2010). Ono se može kombinovati sa konvencionalnim GIS-ovima koji koriste hardverske senzore, kao što su seizmički senzori in situ ili daljinski (aerofotografisanje i satelitsko snimanje), sa ciljem da se izgradi koherentna slika o situaciji na terenu, koja će pomoći pri alokaciji resursâ, proceni štete i prioritizaciji.

Za procenu štete se sve više koriste slike sa bespilotnih letelica (Unmanned Aerial Vehicles, UAV). Međutim, za razliku od lakoće dobijanja ovih slika u visokoj rezoluciji, njihova analiza ostaje izazovan zadatak. Zato se razvijaju različiti modeli veštačke inteligencije koji bi mogli da automatski detektuju oštećene zgrade u dolaznim slikama. ${ }^{1}$ Podaci o šteti se mogu dobiti i analizom poslatih Twitter-poruka koje se odnose na kriznu situaciju, gde se uz pomoć alata za semantičku analizu i kolaborativne baze znanja otkrivaju informacije o lokaciji i veličini štete, koje se koriste za izradu interaktivne krizne mape (Slika 2). Istraživači sa Univerziteta u Tokiju analizom poruka sa Twitter-a donosili su zaključak i o eventualnom nastanku zemljotresa. Na mestima sa tehnološki vrlo obrazovanim korisnicima kao što je Japan, sistem je bio u stanju da stvarne događaje zemljotresa otkrije sa verovatnoćom od čak 96 posto (Sakaki et al., 2010).

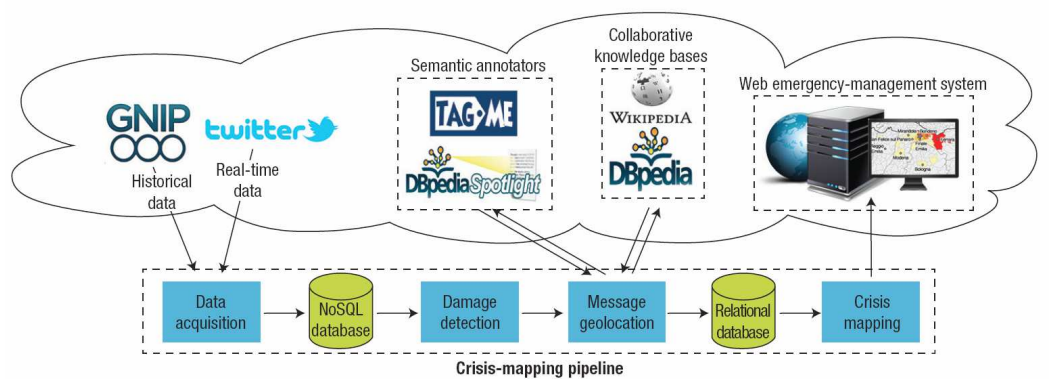

Slika 2. Arhitektura predloženog sistema za krizno mapiranje korišćenjem poruka sa Twitter-a (izvor: Avvenuti et al., 2016)

1 www.micromappers.wordpress.com, pristupano 27. 5. 2017. 
Mnogi su primeri uspešnih e-platformi za krizno mapiranje kao što su Ushahidi ${ }^{1}$ ESRI ArcGIS, ${ }^{2}$ CrisisCommons, ${ }^{3}$ Crisis Cleanup $^{4}$ (Slika 3) i druge. Ove platforme kombinuju automatsko prikupljanje podataka, fuziju podataka i vizuelizaciju, uz učešće korisnika. Kao takvi, to su hibridni crowdsensing sistemi: korisnici mogu dobrovoljno učitavati podatke na sistem, ili se sistem može konfigurisati da automatski vrši prikupljanje podataka ukoliko se pojavi potreba (Poblet et al., 2014).

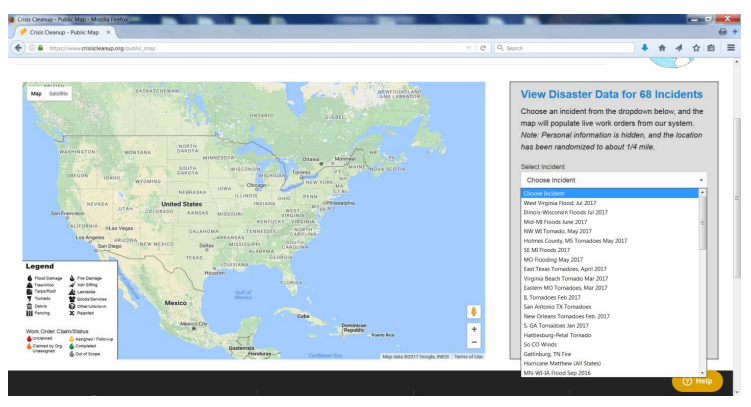

Slika 3. Interaktivna mapa sa podacima o nesrećama ${ }^{5}$

Pored alata za krizno mapiranje, razvijaju se i drugi web-alati za vizuelizaciju. Jedan od njih je alat 'VisAdapt', razvijen sa ciljem da pomogne korisnicima da procene kako će predviđene klimatske promene uticati na njihove domove i identifikovati moguće mere prilagođavanja (Johansson et al., 2017). Mada je u radu prikazan slučaj nordijskih zemalja, on je jasan signal kako će se u budućnosti (čak i za potrebe osiguravajućih kuća radi procene premije osiguranja) sve više razvijati ovakvi alati (Glaas et al., 2015). Tu su i drugi alati ${ }^{6}$ koji na razumljiv način stručnjacima, ali i široj javnosti, pribavljaju vizuelizaciju uticaja klimatskih promena ma gde na Zemlji, a koje se mogu iskoristiti u prvoj fazi upravljanja kriznim situacijama (spremnost).

Međutim, ovi crowdsourced podaci često su nestrukturirani, heterogeni i fragmentirani u velikom broju poruka, tako da zahtevaju prethodnu selekciju, agregaciju i analizu da bi pružili kontekstne informacije koje spasioci mogu koristiti (Besaleva \& Weaver, 2016). Uočena ograničenja društvenih medija odnose se na nepouzdanost tako dobijenih informacija, a nije redak ni slučaj da društvene mreže budu zagušene obmanjujućim (lažnim) informacijama (glasinama) koje mogu dodatno uneti paniku u stanovništvo i gde je potrebno odvojiti dodatne resurse radi njihovog suzbijanja (Murphy, 2016). Vrše se istraživanja koja bi pomogla u razvi-

1 To je platforma za krizno mapiranje otvorenog koda stvorena 2007. godine koja koristi crowdsourcing za prikupljanje informacija i Web 2.0 tehnologije za integraciju podataka iz više izvora (telefoni, e-pošta i društvene mreže). Više na: https://www.ushahidi.com/, pristupano 1. 5. 2017.

2 http://www.esri.com/arcgis/about-arcgis, pristupano 2. 5. 2017.

3 https://crisiscommons.org/, pristupano 2. 5. 2017.

4 https://www.crisiscleanup.org/about, pristupano 2. 5. 2017.

5 Preuzeto sa: https://www.crisiscleanup.org/public_map, pristupano 15. 5. 2017.

6 Više na: www.climatewizard.org i www.climate.gov/maps-data, pristupano 2. 5. 2017. 
janju mehanizama za analizu društvenih medija koji bi doprineli u otkrivanju glasina, pronašli izvor ili verifikovali postavljeni sadržaj (Tapia et al., 2011).

Sledeći izazov kod upravljanja katastrofom jeste prioritizacija podataka. Količina podataka koja se sakuplja i šalje iz ugroženih područja dramatično je povećana. Tu su različiti geoprostorni podaci, slike visoke rezolucije (uključujući one iz UAV) i video-zapisi. Zato se traže nove metode za trijažu slikovnih podataka i za odabiranje toga šta je važno za sve zainteresovane strane. Ovi i drugi izazovi ukazuju na mogućnosti dodatnih istraživanja u oblasti filtriranja podataka, klasifikacije teksta, obrade slike i kognitivnom računarstvu radi rešavanja uočenih problema.

\subsection{Primena IoT-a kod upravljanja vanrednim situacijama}

Prema Gartner-ovoj hype cycle iz 2016. godine (prikazanoj na Dijagramu 1), tehnologija IoT upravo dostiže vrhunac u smislu svesnosti javnosti i njenih očekivanja. Povezivanje uređaja na internet, a posebno senzorâ svih vrsta, nudi ogroman potencijal za poboljšanje uočavanja i procene rizika, za ciljano pokretanje preventivnih mera, kao i personalizaciju ranih upozorenja.

Stvari postaju 'pametne' u smislu da će sofisticirana obrada podataka i komunikacione mogućnosti biti direktno ugrađene u senzore. Ove mogućnosti daju se eksploatisati na dva načina (Uslaender, 2015):

- senzori sa mogućnostima samoopisivanja i bežičnog povezivanja mogu se povezati na lokalnom nivou sa drugim senzorima kako bi se formirale ad hoc senzorske mreže;

- senzor se može iskoristiti za 'poslove nadzora', upotrebom konfigurabilnih politika obaveštavanja prema zainteresovanim potrošačima (npr. poslati obaveštenje samo kada su prekoračeni predefinisani pragovi). Ovakvi senzorski sistemi moraju biti integrisani u ostale IKT sisteme koji deluju kao pružatelji usluga $\mathrm{i}$ informacija drugim sistemima, a za šta je neophodno hitno poboljšati interoperabilnost.

Kada su u pitanju urbane sredine, kompanija Intellistreets predlaže da se stubovi ulične rasvete opreme bežičnim tehnologijama radi obezbeđivanja dodatnih funkcija, kao što su alarmi (upozorenja) za hitne slučajeve, digitalna signalizacija, upozorenja o opasnom okruženju, dvosmerni audio. Uz pomoć ugrađenih senzora mogle bi se prikupiti dodatne informacije iz okruženja (šta se čuje, vidi, miriše i drugo), kao i njihova obrada i analiza na licu mesta.

Zapažanje mogućnosti kakve nude tehnologije nove generacije, koje ljudi mogu koristiti i prilagoditi ne bi li se ojačala njihova vlastita otpornost na krizu i katastrofe, biće neophodni u narednim godinama. Baveći se ovim pitanjima, Međunarodna organizacija društava Crvenog krsta i Crvenog polumeseca izdvojila je, među brojnim novim tehnologijama u razvoju, sledećih osam kao ključne u narednih pet do deset godina: 3D štampači, softver za proširenu stvarnost, biometrijski skeneri, roboti, pametni automobili, senzorske mreže pametnih kuća, bespilotne letelice i nosivi uređaji (wearables) (International Federation of Red Cross and Red Crescent Societies, 2015). 
Tako će senzorske mreže pametnih domova omogućiti prijave požara. Biometrijski skeneri na ATM-kioscima služiće za dobijanje lične dokumentacije za potvrdu identiteta. Uređaji ugrađeni u stvari koje nosimo (Wearable devices) omogućiće rano upozoravanje, potragu i spasavanje, kao i komunikaciono povezivanje porodica, dok će bespilotne letelice, pored snimaka, obezbeđivati i privremeno uspostavljanje komunikacionih veza i mreža (slika 4), kao i dostavu potrebne opreme i materijala (npr. lekovi) ugroženim područjima.

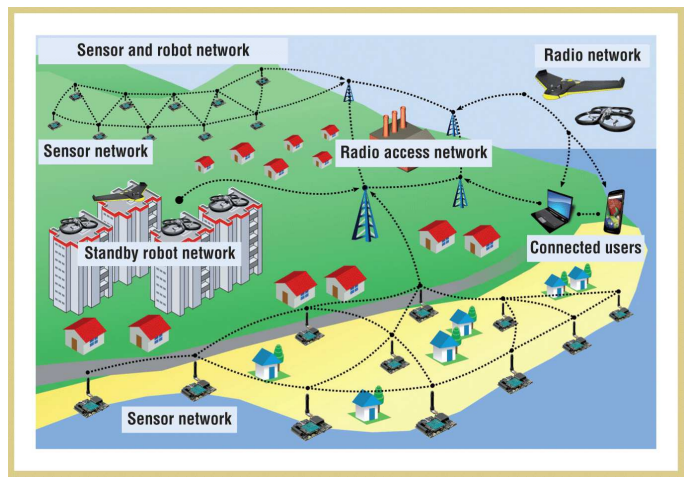

Slika 4. Mogućnost korišćenja bespilotnih letelica u procesu upravljanja vanrednim situacijama (izvor: Erdelj \& Natalizio, 2015)

\section{Zaključak}

Aktivnosti upravljanja vanrednim situacijama zavise od velikog volumena tačnih, relevantnih, pravovremenih geoinformacija koje različiti sistemi sistematski stvaraju i održavaju. Napredak u informacionoj i komunikacionoj tehnologiji u formi interneta, društvenih mreža i medijâ, GIS-a, senzorske tehnologije, satelitske komunikacije, robotizovanih objekata, $I o T$-a i prožimajućeg računarstva može mnogo pomoći u planiranju i implementaciji scenarija smanjenja rizika od katastrofa. Za maksimalnu korist bi trebalo koristiti nove komunikacione tehnologije za pouzdanu razmenu informacija između svih subjekata u procesu upravljanja vanrednom situacijom. Tu se misli na komunikacione satelite, ali i na društvene mreže i medije koji su se pokazali kao izuzetno korisni u slučajevima katastrofa. GIS i krizno mapiranje mogu značajno pomoći kod analize nastanka, samog reagovanja, kao i procene posledica u slučaju nastanka vanredne situacije. Senzorske tehnologije, sa druge strane, mogu efektivno doprineti identifikaciji opasnih područja, nadgledati promene u realnom vremenu i obezbediti rano upozoravanje na predstojeće katastrofe.

Zato treba nastaviti istraživačke aktivnosti na projektovanju, razvoju i pružanju otvorene, skalabilne, pouzdane i sigurne informaciono-komunikacione infrastrukture u cilju podrške svim fazama upravljanja vanrednom situacijom. Ovakva 
ICT infrastruktura trebalo bi da obuhvati senzore i aktuatore svih vrsta, mogućnosti za obradu podataka i data mining kao servise, prilagođen i korisnički specifičan prikaz informacija, fleksibilnu i jednostavnu podršku za odlučivanje, kao i kapacitete prenosa informacija svim zainteresovanim subjektima na pouzdan način.

Međutim, za efikasno i efektivno korišćenje moderne tehnologije u upravljanju vanrednim situacijama neophodno je izvršiti i odgovarajuću obuku i pripremu ljudskih resursa za korišćenje IKT (pre svega svojih mobilnih uređaja) kako bi procenili rizike, podržali rano upozoravanje na katastrofe, ponašali se adekvatno u kriznim situacijama i podržali efikasnu procenu štete.

\section{Literatura}

1. Avvenuti, M., Cresci, S., Vigna, F. D., \& Tesconi, M. (2016). Impromptu Crisis Mapping to Prioritize Emergency Response. Computer, 49(5): 28-37. doi: 10.1109/mc.2016.134

2. Badiru, A.B and Racz, L.A. (2013). Handbook of Emergency Response: A Human Factors and Systems Engineering Approach, CRC Press.

3. Besaleva, L., and Weaver, A.C. (2016). Applications of Social Networks and Crowdsourcing for Disaster Management Improvement, Computer, 49(5): 47-53.

4. Columbus, L. (2016). Roundup Of Internet Of Things Forecasts And Market Estimates, na: https://www.forbes.com/sites/louiscolumbus/2016/11/27/roundup-of-internet-of-things-forecasts-and-market-estimates-2016/\#209a2864292d, pristupano 13. 5. 2017.

5. Cvetković, V. (2016). Uticaj zaposlenosti na spremnost građana za reagovanje na prirodnu katastrofu izazvanu poplavom, NBP, 21(2): 49-71. doi: 10.5937/nbp1602049C

6. Erdelj, M., and Natalizio, E. (2015). UAV-assisted disaster management: Applications and open issues, In Proc. of International Conference on Computing, Networking and Communications (ICNC), 2016. Dostupno na: https://www.researchgate.net/publication/301710340_UAV-assisted_disaster_management_Applications_and_open_issues, pristupano 15. 5.2017.

7. Feki, M.A., Kawsar, F., Boussard, M., Trappeniers, L. (2013). The Internet of Things: The Next Technological Revolution. Computer, 46(2), 24-25.

8. Glaas, E. et al. (2015). Increasing House Owners' Adaptive Capacity: Compliance between Climate Change Risks and Adaptation Guidelines in Scandinavia, Urban Climate, 14(1): 41-51.

9. Gligorijević, M., Bošković, M., Maksimović, A. (2017). The role and importance of the "national roaming" in emergencies', NBP, No 1, pp. 111-126. doi: 10.5937/ nabepo22-12916

10. Goolsby, R. (2010). Social Media as Crisis Platform: The Future of Community Maps/Crisis Maps, ACM Trans. Intelligent Systems and Technology, 1(1): article no. 7.

11. International Federation of Red Cross and Red Crescent Societies. (2015). A Vision for the Humanitarian Use of Emerging Technology for Emerging Needs. Strengthening Urban Resilience. Dostupno na: http://www.ictworks.org/2015/03/25/ a-vision-for-humanitarian-uses-of-emerging-technology-for-emerging-needs/, pristupano 15. 4. 2017.

12. Johansson, J., Opach, T., Glaas, E., Neset, T.S., Navarra, C., Linner, B.O., Rod, J.K. (2017). VisAdapt: A Visualization Tool to Support Climate Change Adaptation, IEEE Computer Graphics and Applications, 37(2): 54-65. 
13. Mattern, F. (2001). Ubiquitous Computing Infrastructures, ERCIM News, dostupno na: https://www.vs.inf.ethz.ch/about/dsg-brochure.pdf, pristupano 10. 4. 2017.

14. McMillin, B. and Zhang T. (2017). Fog Computing for Smart Living, Computer, 50(2): 5-5, Feb. 2017. doi: 10.1109/MC.2017.57

15. Meier, P. (2011). New information technologies and their impact on the humanitarian sector. International Review of the Red Cross, 93(884): 1239-1263. doi: $10.1017 / \mathrm{s} 1816383112000318$

16. Murphy, R.R. (2016). Emergency Informatics: Using Computing to Improve Disaster Management. Computer, 49(5): 19-27. doi: 10.1109/mc.2016.135

17. Murphy, R. et al. (2012). CRICIS: Critical Real-Time Computing and Information Systems, Computing Community Consortium Report, dostupno na: http://archive2. cra.org/ccc/files/docs/Visioning/CCC_CRICIS_REPORT.pdf, pristupano 21. 4. 2017.

18. Pitt, J., Bourazeri, A., Nowak, A., Roszczynska-Kurasinska, M., Rychwalska, A., Rodriguez, S.I., Lopez, S.M., Florea, M., Sanduleac, M. (2013). Transforming Big Data into Collective Awareness. Computer, 46(6), pp. 40-45, doi: 10.1109/mc.2013.153

19. Pittman, E. (2012). 3 Emerging Technologies That Will Impact Emergency Management, dostupno na: http://www.emergencymgmt.com/disaster/3-EmergingTechnologies-Emergency-Management.html, pristupano 17. 5. 2017.

20. Poblet, B.M., Garcia-Cuesta, E. and Casanovas, P. (2014). Crowdsourcing tools for disaster management: a review of platforms and methods. AI Approaches to the Complexity of Legal Systems - Lecture Notes in Computer Science, 8929: 261-274.

21. Popović, B.M., Banđur, M., Raičević, A. (2014). Security challenges of modern technologies utilization. Thematic conference proceedings of international significance 'Archibald Reiss Days', 3-4 March 2014, Belgrade, Academy of Criminalistic and Police Studies, Vol. I, pp. 95-105.

22. Sakaki, T., Okazaki, M. and Matsuo, Y. (2010). Earthquake Shakes Twitter Users: Real-time Event Detection by Social Sensors, In Proc. 19th Int'l Conf. World Wide Web (WWW 10), pp. 851-860.

23. Spence, R. (2014). Information Visualization: An Introduction, Springer, Berlin et al.

24. Tapia, A.H., Bajpai, K., Jansen, B.J. \& Yen, J. (2011). Seeking the Trustworthy Tweet: Can Microblogged Data Fit the Information Needs of Disaster Response and Humanitarian Relief Organizations, Proceedings of the $8^{\text {th }}$ International ISCRAM Conference - Lisbon, Portugal, dostupno na: http://www.iscramlive.org/ISCRAM2011/proceedings/papers/161.pdf, pristupano 16. 4. 2017.

25. Tapscott, D., Tapscott, A. (2016). Blockchain Revolution: How the Technology Behind Bitcoin Is Changing Money, Business, and the World. Portfolio/Penguin, New York.

26. Tung, L. (2017). IoT devices will outnumber the world's population this year for the first time. Dostupno na: http://www.zdnet.com/article/iot-devices-will-outnumber-the-worlds-population-this-year-for-the-first-time/, pristupano 18. 5. 2017.

27. Underwood, S. (2010). Improving Disaster Management, Communications of the ACM, 53(2): 18-20, doi: 10.1145/1646353.1646362

28. Uslaender, T. (2015): The trend towards the Internet of Things: what does it help in Disaster and Risk Management?, Planet@Risk, 3(1): 140-145, Davos: Global Risk Forum (GRF Davos).

29. Vermesan, O., Bacquet J. (2017). Cognitive Hyperconnected Digital Transformation Internet of Things Intelligence Evolution, River Publishers, http://www.internet-ofthings-research.eu/pdf/Cognitive_Hyperconnected_Digital_Transformation_IERC_2017_Cluster_eBook_978-87-93609-10-5_P_Web.pdf, pristupano 22. 4. 2017. 
30. Wattegama, C. (2007). ICT for Disaster Management. United Nations Development Programme - Asia-Pacific Development Information Programme (UNDP-APDIP) and Asian and Pacific Training Centre for Information and Communication Technology for Development.

31. Weiser, M. (1991). The Computer for the 21st Century. Scientific American, 265(9): 66-75.

32. Yuriyama, M. and Kushida, T. (2010). Sensor-Cloud Infrastructure - Physical Sensor Management with Virtualized Sensors on Cloud Computing, In Proceedings of the 13th international conference on NBiS, 2010: 1-8.

\section{INFORMATION AND COMMUNICATION TECHNOLOGY IN EMERGENCY MANAGEMENT}

\section{Summary}

The Law on Emergency Situations (Sl. glasnik RS, No. 111/2009, 92/2011 \& 93/2012) in Article 8, Item 1, defines an emergency as 'a condition in which the risks and threats or the consequences of disasters, emergencies and other threats for the population, the environment and property are of such scale and intensity that their occurrence or effects cannot be prevented or eliminated through regular activity of the competent authorities and services, and for the mitigation or elimination of which special measures, forces and means at higher operational regime are required'. Here, the disaster is assumed to be a natural disaster or other accident or event whose size, intensity and suddenness threatens the health and lives of a large number of people, property and the environment, as well as accidents caused by war destruction or act of terrorism. Emergency Management (Zakon o vanrednim situacijama, Sl. glasnik RS, No. 111/2009, 92/2011 \& 93/2012, paragraph 8, point 17) is the process of organization and management of resources and responsibilities for addressing all aspects of emergencies in particular preparedness, response and initial recovery steps, in order to mitigate the effects of disasters (Cvetković, 2016). The effectiveness of the response depends on the ability to quickly assess the situation and mobilize the necessary resources, which is greatly facilitated by the use of information and communication technology (ICT) and systems.

Nowadays activities in modern society are based on almost unlimited access to information (from any place at any time), making it increasingly reliant and virtually dependent on the use of the Internet and modern technology in a network environment. There are many aspects of the ICT development but we can say that in recent years the focus has been on (Popović, Banđur, Raičević, 2014):

- convergence of networks and services, and the continued evolution of cellular and other wireless networks, mobile operating systems and applications;

- development and personalization of the Internet through the introduction of location-based services that use information about the physical location of a user or device in order to provide targeted information;

- mapping of physical objects into cyber subjects with the possibility of mutual (smart) interaction - Internet of Things (IoT); 
- $\quad$ expansion of social media and social networks and the use of web-based computer systems - cloudcomputing;

- production and distribution of content across multiple platforms.

Data analysis and information processing from distributed data sources and large sensor networks (big data analytics) is performed in order to make better decisions, but also in the context of understanding the place of their creation for the perception and understanding of what is happening in a complex environment (Situational awareness), which is of particular importance for security, surveillance, emergency management, environmental monitoring etc. Integrating social and sensor networks can transform 'big data' into a higher form of collective awareness, where data mining and visualization technology make it possible to detect trends and predict the trajectory of higher level variables (Pitt, J. et al. 2013).

When it comes to emergency management, in the study (Murphy R. et al. 2012) from 2012, seven ways in which ICT can promote this process are identified including: improved acquisition of a priori and real-time data; transmit and transform the data into actionable information which help to provide accurate situation awareness across all echelons of decision makers; optimize resource usage and logistics; tool to help in the recovery, to reunite families, identify and triage victims etc.

There is a clear need to gather, analyse and disseminate reliable and timely information in the midst of chaotic environment caused by the disaster. Implementation of integrated Information System (IS) can provide an adequate information flow in real time in order to facilitate decision-making. The introduction of spatial data features in the IS or the use of so-called Geographic Information Systems (GIS) enables visualization and generation of so-called 'Risk maps', as well as forecast the possible development of risk factors. Connecting technologies such as IoT, smart sensors and pervasive (ubiquitous) computing with wearable and handheld computers, wireless communication networks and sensor networks are vital for the efficiency improvement in emergency response.

Special attention is devoted to communication technologies and platforms for the establishment of a safe and fast way of informing in the affected area. In this sense, especially in urban areas, social media can be used for distribution of vital information to vulnerable population, but also as a tool for communication and obtaining relevant information both from citizens (crowdsourced) and members of the rescue teams, during a catastrophic event (Meier, 2011). For example, during Hurricane Sandy in Central and North America and Emilia earthquake in Italy, both in 2012, as well as in Nepal earthquake in 2015, mobile devices and social media were used for information exchange (Avvenuti, Cresci, Vigna, Tesconi, 2016). The unreliability of this crowdsourced information is considered as the main disadvantage (Tapia et al. 2011), followed by the situation (which is not a rare case) when social networks are congested by misleading (false) information (rumour) that can additionally enter panic in the population and where it is necessary to deploy additional resources for their suppression (Murphy, 2016). These and other challenges point to the possibilities of additional research in the area of data filtering, text classification, image processing, cognitive computing, etc. in order to address the identified problems.

Keywords: information and communication technologies - ICT, emergency management, social networks, crowdsourcing 